\title{
THE IMPLEMENTATION OF JUMBLED-SENTENCES TOWARD STUDENTS' SKILL IN WRITING REPORT TEXT
}

\author{
Fatmawati Setia Utami \\ English Education Department, Faculty of Education, Universitas Teknologi Yogyakarta, Indonesia \\ E-mail: fatmatami73@gmail.com \\ Mustaqim Pabbajah \\ Guidance and Counseling Department, Faculty of Education, Universitas Teknologi Yogyakarta, \\ Indonesia \\ E-mail: mustaqim_pabbajah@uty.ac.id
}

\begin{abstract}
Juhansar
English Education Department, Faculty of Education, Universitas Teknologi Yogyakarta, Indonesia E-mail: juhansar@uty.ac.id
\end{abstract}

APA Citation: Utami, F. S., Pabbajah, M., \& Juhansar, J., (2018). The implementation of jumbledsentences toward students' skill in writing report text. English Review: Journal of English Education, 7(1), 115-124. doi: 10.25134/erjee.v7i1.1501.

Received: 19-08-2018

Accepted: 25-10-2018

Published: 01-12-2018

\begin{abstract}
This study aims at describing the implementation and the effectiveness of jumbledsentences as a technique to enhance students' skill in writing report text and finding out the factors influencing students' skill in writing report text. This study was conducted in MAN 2 Yogyakarta that involved 24 tenth graders of IPA 3 in academic year 2018/2019. This study was a classroom action research. To collect the data, observation checklist, structured interview, and tests were used. The result showed that most of students could understand the subject easily and involve actively during the technique implementation. Besides, the test results showed students' mean improvement in writing report text from pre-test (3.00), post-test I (3.36), and post-test II (3.78). It means that jumbled-sentences technique is effective to enhance students' skill in writing report text. Moreover, the factors influencing students' writing skill were having lack of vocabulary, getting anxiety in making grammar errors, getting difficulties in understanding and translating words or sentences, and having limited classroom for learning-teaching process.
\end{abstract}

Keywords: implementation; jumbled-sentences; students' skill; writing; report text.

\section{INTRODUCTION}

Writing is an activity of expressing and developing idea in a written form. Writing is also known as a recursive process involves a series of steps to create a good and a correct text. Pestaria, et al. (2014) said that writing is one of the four skills that has always formed part of the syllabus in teaching English. It means that no one can deny writing as the part of syllabus in English subject. In English education, learning to write is a must. Through writing, students can write the words by arranging them into a correct order of a sentence. The words in a sentence should be meaningful and understandable by the readers. Therefore, words in English writing cannot be written in any way without following the rules and the structure as the way it should be.

Related to the rules and the structure in writing, some students think that writing is more difficult than other skills because it has certain rules and takes long time to think the words in correct order and to make the readers understand it easily. There are particular structures of texts which usually written in a form of paragraph or essay. Those texts are descriptive, narrative, recount, and report text. Descriptive text describes about someone or something such as place, picture, or people. Narrative text and recount text are kinds of text which tell 
about story in the past time, but narrative and recount have different generic structure in which narrative text has a conflict in the middle of story while recount text does not. Besides, narrative text usually tells about the fictive story such as fable, fairy tale, legend, etc. Meanwhile, recount text tells about true story which comes from the past event or the real experience of the writer. Indeed, report text is a text that gives factual information to the reader.

To write a text, students have to know first the definition and the elements of a paragraph. A paragraph is usually written in logical order from the introduction to the conclusion which consists of topic sentence, supporting sentences, and concluding sentence. In writing a paragraph, the sentences should be arranged orderly and connected each other in explaining the topic of the paragraph. In writing an English paragraph, the students may get difficulties to develop the idea. According to Richards (1990) in Al-Gharabally (2015, p. 44), learning to write well is a difficult and a lengthy process; one that induces anxiety and frustration in many learners. It means that students need to understand first the process of writing in appropriate way. To learn writing a paragraph, students should be able to organize the sentences in a right place. In organizing the sentences, the students have to know the process of writing to achieve the best result.

Based on the researchers' experience when teaching and observing Praktik Pengalaman Lapangan (PPL) at MAN 2 Yogyakarta, it found that most students were unable to write and organize a good and a correct English paragraph because they have less willingness to focus and to enjoy the learning process. Besides, most students tend to be passive and bored when they were learning writing. Some studies have found some common problems in writing including content, organization, vocabulary, and grammar. Sari (2013) described that the common problems would be; students cannot formulate the main ideas and provide the supporting sentences to write a good and a correct paragraph; students are lack of vocabulary so they could not express the ideas and the opinions. Furthermore, students also found difficulties in grammatical aspect where they cannot write the text in a good and a correct sentence structure.

Accordingly, the researchers realized that there should be an appropriate technique to use in overcoming the students' problems in writing an English paragraph. Therefore, the researchers try to implement jumbledsentences technique to help students overcome their difficulties in writing English paragraph. Besides, this technique can also be used to develop students' understanding and participation in the learning-teaching process of report text writing. Jumbledsentences is a technique of teaching writing in which the students are asked to rearrange a group of scramble sentences into a good and a correct order. Jumbled-sentences which is known as jumbled texts is cooperatively sequencing piece of jumbled texts by at first skimming for a meaning to establish a quick order, then scanning for detail to confirm its accuracy (Wright et al., 2006, p. 87). Jumbled-sentences technique helps the students to think creatively and logically to determine the sentences appropriately to be the topic sentence, supporting sentences, and concluding sentence. Jumbled-sentences technique is important to be practiced because through practicing this technique, it can help the students to generate the ideas, to enrich the vocabulary, and to emphasize their writing skill (Mardiana, 2017).

The implementation of jumbledsentences does not only involve the students, but the teacher who has an important role in the learning-teaching process. To connect with the roles of teacher in the learningteaching process, Barnawi (2016) wrote some teacher's roles such as teacher as a facilitator, teacher as a learning conceptor, and teacher as an evaluator. As a facilitator, a teacher should be able to help students in developing and initiating their idea and creativity. Furthermore, the students are also 
ENGLISH REVIEW: Journal of English Education Volume 7, Issue 1, December 2018

asked to be independent in the learningteaching process. By analyzing the students' need and condition, a teacher as a learning conceptor is required to design a good lesson plan to be implemented the learningteaching process and also a good classroom management (Juhansar, et al., 2016). A learning conceptor also should decide the appropriate media to set a conducive classroom and to increase the students' learning-teaching interest. Indeed, when a teacher acts as an evaluator, he or she should measure the objective and the learningteaching achievement based on the information that he has. The information can be collected through an observation or an exercise given to the students. It can be guidance for a teacher to continue, to fix, to change, or to evaluate the method or technique which has been implemented.

Murray (2011, p. 157) said that there are two learning-teaching instruction strategies, namely gradual release practice and independent practice. Gradual release practice is a strategy of teaching where a teacher guides the students practically and gradually till they could understand and practice the work by themselves or in pair. Otherwise, independent practice means that a teacher gives an opportunity to students to practice and to explore their understanding based on the material that they have learnt without teacher's guidance and assistance. All in all, to overcome students' problems in writing report text and to enhance students' writing skill, the researchers explore the following research questions to be answered: 1) what is the implementation of jumbledsentences toward the students' skill in writing report text?; 2) what is effectiveness of jumbled-sentences technique toward students' writing skill?; and 3) what factors are influencing students' skill in writing report text?.

\section{METHOD}

This research was conducted on 24 tenthgraders of IPA 3 in MAN 2 Yogyakarta in academic year 2017/2018 for two weeks. This research was classroom action research
p-ISSN 2301-7554, e-ISSN 2541-3643

https://journal.uniku.ac.id/index.php/ERJEE

using qualitative and quantitative data. This research design consisted of two cycles. Each cycle had two meetings. It means, there were four meetings in two cycles.

In collecting qualitative data, the researchers used structured observation and structured interview, while tests used to get the quantitative data. To get data concerning the implementation of jumbled-sentences technique, the researchers used structured observation, while the data concerning the factors influencing students' writing skill were collected through structured interview which was supported by structured observation. Moreover, tests were used to find out the effectiveness of jumbledsentences in improving students' writing skills. The tests consisted of pre-test, posttest I, and post-test II. To know the students' initial writing skills, a pre-test conducted.

In analyzing qualitative data, the researchers set paragraph scoring criteria which consisted of some aspects, namely topic sentence, supporting sentences, coherence, organization, and generic structures. When the paragraph scoring criteria has been set, the researchers decided the technique of analyzing the result of structured observation and structured interview data. To analyze the structured observation data, the researchers described it by mapping, reviewing, and exploring the data during the implementation of jumbledsentences. After analyzing the structured observation data, the researchers also analyzed the structured interview data by reporting and interpreting what the researchers got from the research. When the interview data reported and interpreted, the researchers described the result of the analysis based on the relevant theories. Furthermore, to analyze the quantitative data, the researchers used statistic descriptive method by calculating the mean of writing aspects and the mean of improvement percentage. Indeed, to decide the students' mean, the researchers determined the criteria as follows: 5 (Very good), 4 (Good), 3 (Fair), 2 (Poor), and 1 (Very poor). 
After deciding the technique of data analysis, the researchers measured students' writing skill and pre-understanding about report text by giving pre-test. Here, the students were asked to write the text which consisted of 2 paragraphs contained topic sentence, supporting sentences, coherence, organization, and generic structures. After giving pre-test, the researchers made lesson plans and prepared the report text material, jumbled-sentences texts, and students' worksheets as the next task for post-test I and post-test II to be conducted in cycle I and cycle II. Moreover, the researchers prepared the structured observation sheets and structured interview questions. After preparing those items, the researchers implemented jumbled-sentences as the treatment during the learning-teaching activity about report text in the first meeting of cycle I. The researchers did not only implement technique, but also observed the implementation and learning-teaching activity in the first meeting. In the second meeting of cycle I, the researchers gave post-test I to measure the students' writing skill improvement after receiving the treatment. In giving post-test I, the students were asked to write a report text about technology around them in 40 minutes. After conducting cycle I, the researchers evaluated result of jumbled-sentences implementation including the result of observation and posttest I, whether it needs development or not.

In addition, the researchers also determined the minimum mean as the consideration for conducting the creativity and innovation in cycle II to achieve the better result. The creativity and innovation were necessary to do when the students got mean less than 3 . The creativity and innovation were in the form of changing the setting of learning-teaching process and changing the teaching strategy as well as the way of jumbled-sentences technique implementation. After deciding the creativity and innovation, the researchers conducted cycle II which had similar activity in cycle I. Furthermore, the activity in cycle II might be different based on creativity and innovation as the result of the reflection in cycle I. In cycle II, the researchers re-explained the material and implemented jumbledsentences as the individual task in the third meeting to make the students understand more about the report text. The researchers also changed the teaching strategy from independent practice to gradual release practice. In the fourth meeting of cycle II, the researchers gave post-test II by asking the students to write a latest report text on technology in 40 minutes. When the learning-teaching process was done, the researchers interviewed some students. After conducting those cycles, the researchers analyzed the whole results to consider whether the cycle should be continued or stopped.

\section{RESULTS AND DISCUSSION The implementation of jumbled-sentences technique in teaching report text}

As the results of the implementation, it was found that students were enthusiastic and active in the learning-teaching process. The script below shows that the student tried to be confident to ask the material that they have not understood yet. The script was taken from observation during the jumbledsentences implementation in cycle I.

\begin{tabular}{|ll}
\hline Student A & Pak, kalau misal di bagian general classification itu \\
& dideskripsikan dulu penemunya baru definisikan bisa gak? \\
& (Sir, could I describe the inventor first then define the general \\
& classification? [Free translation]) \\
Researcher(s) : & Ya bisa, atau lebih baik definisi dulu baru deskripsikan \\
penemunya. & (Yes, it could be or it is better to define first then describe the \\
& inventor. [Free translation]) \\
Observation; April $26^{\text {th }}, 2018$
\end{tabular}


ENGLISH REVIEW: Journal of English Education Volume 7, Issue 1, December 2018

Based on that script, even though there was a student who asked about the general classification of report text, there were some students who felt difficult to rearrange the jumbled-sentences because there were some vocabularies that they did not understand,
p-ISSN 2301-7554, e-ISSN 2541-3643

https://journal.uniku.ac.id/index.php/ERJEE

such as since, bulb, filament, and crockery. In addition, when students wrote a report text, some of them were still confused to decide what they want to write and how to develop the idea as it is shown in the following script:

\begin{tabular}{|lll|}
\hline Student B & Pak, aku mau nulis apa ya Pak? Kalau tentang teknologi, \\
& biasanya apa aja? \\
& (Sir, what should I write? If I write about technology, what \\
& technology is it about? [Free translation]) \\
Researcher(s) : & Kamu bisa menulis tentang teknologi yang ada di sekitarmu, \\
& seperti handphone, kipas angin, dan lain-lain. \\
& (You could write about technology around you, such as \\
& handphone, fan, etc. [Free translation]) \\
Student C $:$ & Pak, setelah menulis definisi dan ciri-ciri, terus apa lagi Pak? \\
& (Sir, what should I write after writing the definition and \\
& characteristic of the topic? [Free translation]) \\
Researcher(s) : & Kamu bisa menuliskan tentang fungsi dan jenis-jenis dari \\
& teknologi yang kamu tulis. \\
& (You could write about functions and kinds of the technology. \\
& [Free translation])
\end{tabular}

Based on the script, it could be said that the use of jumbled-sentences could make the students be active and enthusiastic in learning-teaching process and help them in writing report text. Yet, there were some students who still found difficulties to decide what they want to write and how to develop the idea. Therefore, the researchers needed to revise the planning creatively and innovatively to achieve the better result and to overcome students' difficulties in the next cycle.

Based on the result in cycle I, there was unsatisfied result which made the researchers should revise some aspects related to the learning-teaching process such as students' participation and understanding. Therefore, the researchers revised the planning. In cycle II, the researchers conducted the learning-teaching process based on the creativity and innovation. In the third meeting of cycle II, the researchers asked the students to rearrange jumbledsentences individually using gradual release strategy. The changing of rearranging sentences individually aimed at making students understood more about the report text and the basic organization of paragraph such as topic sentence, supporting sentences, and concluding sentence. It also made them be able to create a good organization and a coherence text. The changing of gradual release practice also meant to make the students be more active and confident to ask the material that they did not understand yet. Mushola is also chosen as the setting of learning-teaching process to make the learning-teaching process be more conducive. In the fourth meeting, cycle II, the researchers taught the students in the third floor of library to make them be more focus and concentrate to the learningteaching process especially when they were writing a report text about the latest technology as the post-test II.

After conducting cycle II, the researchers found that the observation result in this cycle increased from the result of cycle I. The students were more active in the learningteaching process. They were also enjoyed and understood more about report text and the basic organization of a paragraph. Those improvements were proved in this following script: 
Fatmawati Setia Utami, Mustaqim Pabbajah, \& Juhansar

The implementation of jumbled-sentences toward students' skill in writing report text

\begin{tabular}{|c|c|}
\hline Student E & $\begin{array}{l}\text { Pak, gimana sih cara membedakan kalimat-kalimat yang } \\
\text { masuk ke general classification sama bagian description? } \\
\text { (Sir, how to differentiate the sentences which are included in } \\
\text { general classification and description? [Free translation]) }\end{array}$ \\
\hline Researcher(s) & $\begin{array}{l}\text { Kalau kalimat-kalimat di general classification biasanya } \\
\text { menjelaskan topik secara umum, seperti definisi dan penemu } \\
\text { suatu teknologi. Sedangkan kalimat di bagian description } \\
\text { merupakan kalimat-kalimat khusus yang menjelaskan bagian } \\
\text { general classification. } \\
\text { (The sentences in general classification usually explain the } \\
\text { topic generally such as definition and the inventor of } \\
\text { technology. In description, the sentences explain the general } \\
\text { classification specifically. [Free translation]) } \\
\text { Observation; May } 3^{\text {th }}, 2018\end{array}$ \\
\hline Student F & $\begin{array}{l}\text { Pak, topic sentence itu biasanya yang di awal paragraf kan? } \\
\text { (Sir, the topic sentence is usually put in the beginning of the } \\
\text { paragraph, isn't it? [Free translation]) }\end{array}$ \\
\hline Researcher(s) & $\begin{array}{l}\text { Ya, tapi kadang ada juga yang letaknya di akhir paragraf. } \\
\text { (Yes, it is. But, sometimes there is also topic sentence which is } \\
\text { put in the end of paragraph. [Free translation]) }\end{array}$ \\
\hline Student G & $\begin{array}{l}\text { Pak, kalau bagian deskripsi di report teks itu biasanya jelasin } \\
\text { tentang ciri-ciri dan fungsi apa bukan? } \\
\text { (Sir, does the description part of report text explain about the } \\
\text { characteristics and the function of the text? [Free translation]) }\end{array}$ \\
\hline Researcher(s) & $\begin{array}{l}: Y a . \\
\text { (Yes, it does. [Free translation]) }\end{array}$ \\
\hline
\end{tabular}

After implementing the creativity and innovation toward the jumbled-sentences implementation in both cycle I and cycle II, most of students were no longer confused to decide what they wanted to write, how to develop the sentences, and how to organize the sentences related to the generic structures of report text. In addition, the observation result showed that the students' participation, understanding, and writing development on the report text using jumbled-sentences were better than previous one. The students became more aware about report text and its generic structures. Moreover, students enjoyed practicing jumbled-sentences because they got intensive guidance from the researchers. It meant that the implementation of jumbledsentences as the teaching technique for writing report text could help the students in developing the idea and organizing sentences into a good and a correct paragraph. The choosing of place for learning-teaching also supported the students to be more focus to the learning-teaching process because it helped the researchers to create the classroom atmosphere to be more conducive. The cycle I and the creativity and the innovation in cycle II drove the researchers to end the cycle because there were students' better participation and students' better understanding during the learning-teaching process. It meant that students were aware to be actively involved in the learning-teaching process.

\section{The effectiveness of jumbled-sentences technique toward students' skill in writing report text}

The researchers was not only describing the result of observation but also providing the analysis result of students' writing tests. Based on the result of data analysis, it was found that there was students' mean improvement on each aspect. From the result, the students got mean 3.00 (pre-test); 
ENGLISH REVIEW: Journal of English Education Volume 7, Issue 1, December 2018

3.36 (post-test I); and 3.78 (post-test II). It means that the use of jumbled-sentences could help the students to understand the report text better. In addition, it also proved
p-ISSN 2301-7554, e-ISSN 2541-3643

https://journal.uniku.ac.id/index.php/ERJEE

that jumbled-sentences could improve the students' writing skill on each aspect. To make it clear, the researchers showed the mean improvement in Table 1.

Table 1. The improvement of students' mean

\begin{tabular}{clccc}
\hline \multirow{2}{*}{ No } & \multicolumn{1}{c}{ Aspects } & \multicolumn{3}{c}{ Mean } \\
\cline { 3 - 5 } & & Pre-test & Post-test I & Post-test II \\
\hline 1 & Topic Sentence & 2.96 & 3.25 & 3.79 \\
2 & Supporting Sentences & 2.75 & 3.25 & 3.71 \\
3 & Coherence & 3.17 & 3.33 & 3.46 \\
4 & Organization & 3.13 & 3.42 & 3.75 \\
5 & Generic Structures & 3.00 & 3.54 & 4.17 \\
\hline \multicolumn{2}{c}{ Overall Mean } & $\mathbf{3 . 0 0}$ & $\mathbf{3 . 3 6}$ & $\mathbf{3 . 7 8}$ \\
\hline \multicolumn{2}{c}{ \% Improvement } & \multicolumn{2}{c}{$\mathbf{1 2 \%}$} \\
\hline
\end{tabular}

Table 1 shows the mean improvement of students' pre-test (3.00), post-test I (3.36), and post-test II (3.78) on each aspect. In the column of pre-test, there are two aspects which belong to category Poor (2), namely topic sentence and supporting sentences. The table also shows the mean in both topic sentence and supporting sentences are more than 2 and less than 3. It means that jumbled-sentences implementation is needed to practice for increasing the students' mean in those aspects. When the jumbledsentences was practiced, the researchers gave post-test I to measure the students' result and improvement in writing skill, whether it needs to do the creativity and innovation or not.

Based on the result in the column of post-test I, there is no aspects which belong to category Poor (2). There is good improvement in all aspects in the result of post-test I. In the result of post-test I, all the mean on each aspect belongs to Fair (3) category. It means that jumbled-sentences technique helps the students to improve their writing skill, not only in topic sentence and supporting sentences aspects but also in other aspects. Although there is an improvement in all aspects, it does not mean that the result is satisfied and no need to do creativity and innovation. From the result of post-test $\mathrm{I}$, there is similar mean in the aspects of topic sentence (3.25) and supporting sentences (3.25). It means that the researchers should do the creativity and innovation in cycle II before conducting post-test II. After practicing jumbledsentences and applying the creativity and innovation in cycle II, the researchers gave post-test II to measure the mean improvement of students' writing skill and the effectiveness of jumbled-sentences technique. The result of post-test II shows better improvement than post-test I. In the column of post-test II, there is no mean which less than 3 even more than 4 in aspect of generic structures. Besides, there is no similar mean in all aspects as the previous result in post-test I. Furthermore, there is also mean improvement percentage among the aspects of writing about $12 \%$ (from pretest to post-test I) and $13 \%$ (from post-test I to post-test II). In short, the use of jumbledsentences is effective to help the students in understanding the material, developing the idea, and improving their writing skill.

\section{Factors influencing students' skill in writing report text}

After analyzing the result of observation and tests, the researchers described the result of interview with the students to see the factors influencing their skill in writing report text. From the interview, there were at least four common problems faced by the students, they are: 
Fatmawati Setia Utami, Mustaqim Pabbajah, \& Juhansar

The implementation of jumbled-sentences toward students' skill in writing report text

Lack of vocabulary and information

When the researchers interviewed students, they said that their obstacle in writing report text were lack of vocabulary and information. It was proved by the interview data below.

\begin{tabular}{|lll|}
\hline Researcher(s) $:$ & $\begin{array}{l}\text { Kendala apa yang kalian alami saat menulis report text? } \\
\text { (What is your obstacle in writing report text? [Free } \\
\text { translation]) }\end{array}$ \\
Student 1 & $: \begin{array}{l}\text { Kurang data atau informasi Bu. } \\
\text { (I have less data or information, Mom. [Free translation]) }\end{array}$ \\
Student 2 & $: \begin{array}{l}\text { Kurang vocabulary Bu. } \\
\text { (I am lack of vocabulary, Mom. [Free translation]) }\end{array}$ \\
Student 3 $: \quad \begin{array}{l}\text { Sama Bu, kurang vocabulary. } \\
\text { (I have the same problem with Student 2, Mom. I am also lack } \\
\text { of vocabulary. [Free translation]) }\end{array}$ &
\end{tabular}

The researchers also found this factor during the observation when implementing jumbled-sentences as a technique in learning-teaching process. When implementing the technique, some students were confused to rearrange the sentences. They also did not bring pocket dictionary then asked the researchers. The following is the script.

Observation; May $26^{\text {th }}, 2018$

Based on those results, it means that lack of vocabulary and information influenced students' skill in writing a report text because without having enough vocabulary and information, they could not develop their idea.

\section{Being afraid of making grammatical errors} Besides vocabulary and information, students' anxiety also could be the factor influencing students' writing skill. When they were afraid, they were not able to focus and concentrate in writing their ideas. Below is student statement about anxiety.

\begin{tabular}{|lll|}
\hline Researchers & $:$ & Kendala apa yang kalian alami saat menulis report text? \\
& (What is your obstacle in writing report text? [Free translation]) \\
Student $4:$ & Takut pola grammarnya salah Bu. \\
& (I am afraid of making mistake in grammatical pattern, \\
& Mom. \\
& [Free translation] $)$
\end{tabular}

Based on that statement, it means that students who were afraid to make mistake would think more and more to avoid making a mistake. Finally, it would make them be longer to write and it of course influences the result of the task. 
ENGLISH REVIEW: Journal of English Education Volume 7, Issue 1, December 2018

\section{Understanding and translating words or sentences}

To write an English report text, the students are obligated to be able to understand and to translate words or sentences from Bahasa
p-ISSN 2301-7554, e-ISSN 2541-3643

https://journal.uniku.ac.id/index.php/ERJEE

Indonesia to English. Based on the result of interview, a student said that his/her obstacle in writing report text is difficult to understand and to translate the English words. It was proved by the script below.

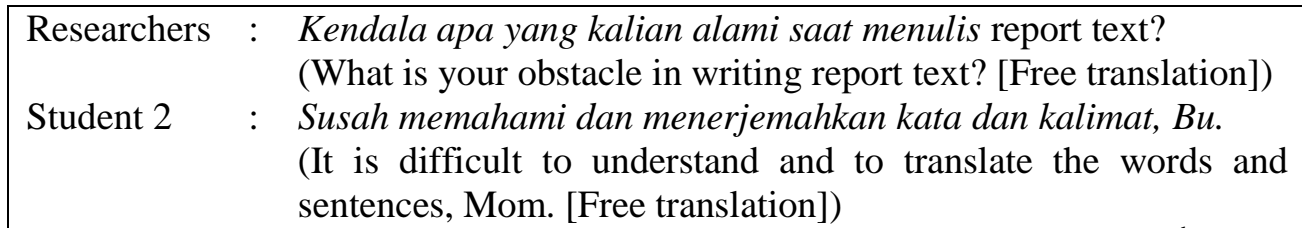

Interview; May $5^{\text {th }}, 2018$
Based on several statements before, besides lack of vocabulary and information, and students' anxiety in making grammatical errors, the students' difficulties in understanding and translating English words also affected the students' work in writing report text. In other words, students' difficulties to understand and to translate words or sentences made them took several minutes to continue their report text writing.

\section{Limited classroom for learning-teaching}

In this factor, the students moved from one classroom to another according to the subject that they learnt. From this situation, sometimes it influenced the students' concentration in learning-teaching process. For example, in class of X IPA 3, the learning-teaching process was conducted in class of X IPS 3, as a consequence, when the learning-teaching process was still running, there were some other students of X IPS 3 came to that classroom before the lesson done. This situation automatically disturbed the focus and concentration of tenth-grade students IPA 3 to finish the work. As a result, some students were not able to finish the work by on their best.

\section{CONCLUSION}

Based on the results of study, the researchers conclude that the implementation of jumbled-sentences in learning-teaching process can help students to develop their report text writing skill performance on the tenth year students of MAN 2 Yogyakarta, class X IPA 3, in academic year 2017/2018. Besides, jumbled-sentences also can attract students' enthusiasm in learning-teaching report text. In addition, the result of students' test also shows the mean improvement percentage from pre-test to post-test I (12\%) and post-test I to post-test II (13\%). It proves that the use of jumbledsentences is effective to help the students in understanding the material and improving the students' writing skill performance to develop the idea to write report text about technology. Furthermore, the researchers also find and sums up some factors influencing students' skill in writing report text. Those factors are lack of vocabulary and information, students' anxiety in making mistakes at grammar, understanding and translating words or sentences, and limited classroom for learning-teaching process.

\section{REFERENCES}

Al-Gharabally, M. (2015). The writing difficulties faced by L2 learners and how to minimize them. International Journal of English Language and Linguistics Research, 3(5), 42-49.

Barnawi \& Arifin, M. (2016). Micro teaching. Yogyakarta: Ar-Ruzz Media.

Juhansar, J., et al. (2016). The implementation of higher order thinking skill at Universitas Teknologi Yogyakarta Indonesia: opportunities and challenges. Proceedings of the international conference on education and hots. Malaysia: Universiti Teknologi Malaysia. https://www.researchgate.net/publication/324720 219 The Implementation of Higher Order Thi nking_Skills at Universitas Teknologi_Yogyak arta in Indonesia_Opportunities and Challenge s/download

Malinda, R. P. (2017). Improving students' writing ability in recount text writing through jumbled sentences at the first grade of SMA Kartikatama Metro. Thesis. Lampung: Universitas Lampung. 
Fatmawati Setia Utami, Mustaqim Pabbajah, \& Juhansar

The implementation of jumbled-sentences toward students' skill in writing report text

Mardiana, N. (2017). Using jumbled sentences game in teaching recount text. Unpublished Thesis. Banten: The State Institute for Islamic Studies Sultan Maulana Hassanudin Banten.

Murray, D. E., \& Mary A. C. (2011). What English language teachers need to know: Facilitating learning. New York: Routledge.

Pestaria, F., et al. (2014). Students' difficulties in writing report text at grade IX of SMP Negeri 5 Tanjungbalai. IOSR Journal of Humanities and Social Science, 19(1), 28-34.

Sari, F. P., et al. (2013). An analysis of students' ability and problems in writing recount texts at grade VIII of SMPN 29 Padang. Journals of English Language Teaching, 2, 73-85.

Tyas, A. S. P. (2012). Using jumbled paragraphs to improve paragraph writing skills of XA students in SMA Mikael Warak Sleman. Unpublished Thesis. Yogyakarta: Sanata Dharma University.

Wardhani, E. P. (2015). Using jumbled sentence games to improve the writing ability of the seventh grade students of MTs Muhammadiyah 6 Bayat Klaten. Unpublished Thesis. Yogyakarta: University of Muhammadiyah Yogyakarta.

Wright, A., et al. (2006). Games for language learning $\left(3^{\text {rd }}\right.$ ed.). New York: Cambridge University Press. 